\title{
DNA fingerprints in Hevea brasiliensis (rubber tree) using human minisatellite probes
}

\author{
PASCALE BESSE*, PATRICIA LEBRUN, MARC SEGUIN \& CLAIRE LANAUD \\ BIOTROP, CIRAD (IRCA), BP 5035, 34032 Montpellier Cedex, France
}

\begin{abstract}
The suitability of DNA fingerprints as genetic markers in Hevea brasiliensis was tested. Using the human minisatellite probe 33.6 , the 73 cultivated (Wickham) clones studied exhibited individualspecific, reproducible and somatically stable hybridization patterns, with stably inherited fragments. This probe has been found to be a powerful new tool for clonal identification as an alternative to isozymatic markers.
\end{abstract}

Keywords: clonal identification, DNA-fingerprinting, Hevea brasiliensis.

\section{Introduction}

Wild Hevea brasiliensis grows in the tropical rain forests south of the Amazon river and covers a wide range of ecological and bioclimatic regions. There are at least nine species of Hevea but the only one cultivated for rubber production is Hevea brasiliensis.

Hevea was introduced from the Amazon basin to Asia at the end of the nineteenth century, and more recently to Africa. The traditional cultivated clones (known as Wickham clones), used for selection work, show a very narrow genetic base because they are all derived from a few seeds (only 9-22) collected by Wickham near the Tapajos river.

Hevea cultivars are vegetatively propagated by grafting, making clonal conformity controls essential. Furthermore, legitimacy controls of crosses are needed to support Hevea breeding programmes.

The lack of useful morphological traits for clonal distinction led to the development of molecular markers. In the past decade, isozyme electrophoresis has been used successfully for these purposes (Chevallier, 1988). Nevertheless, isozyme study is limited by the number of accessible loci and alleles, and requires analysis of several enzymatic systems (Lebrun \& Chevallier, 1990).

In order to improve the number of available markers, RFLP studies were developed on Hevea. Probes for hypervariable regions of the genome may identify a high level of polymorphism, making them extremely useful in RFLP analysis. Certain regions of repetitive DNA give multiallelic RFLP patterns, this higher degree of variability being due to variable

\footnotetext{
*Corresponding author.
}

numbers of tandem repeats (VNTR). The use of these minisatellite hypervariable DNA sequences for generating nuclear fingerprints, originally described in humans (Jeffreys et al., 1985a, b), has been introduced recently into the analysis and characterization of plant genomes (Weising \& Kahl, 1990). The probes used most often are human minisatellite probes of Jeffreys et al. (1985a) (Dallas, 1988; Rogstad et al., 1988a), and M13-derived probes first described by Vassart et al. (1987) (Rogstad et al., 1988b; Nybom et al., 1989; Zimmerman et al., 1989; Nybom \& Rogstad, 1990; Nybom et al., 1990). Simple repetitive sequences can also generate DNA fingerprints in plants (Weising et al., 1989, 1991).

Using human minisatellite probes 33.6 and 33.15 (Jeffreys et al., 1985a), a study was undertaken to determine whether those probes could be used for clonal identification and genetic studies in Hevea brasiliensis.

\section{Materials and methods}

\section{Plant material}

This study was performed on 73 Wickham clones, representing the main cultivated Hevea brasiliensis clones (Table 1). After many years of free crosses between the trees derived from Wickham seeds, grafting allowed conservation and propagation of the best trees of this population, called 'primary clones'. Other clones have since been created by controlled crosses. Thus, Wickham clones represent an inbred population.

Leaves were collected in a collection garden at IDEFOR-IRCA in Côte d'Ivoire, and two samples from distinct trees were taken for each clone. 
Table 1 Wickham clones used in fingerprint analysis

\begin{tabular}{|c|c|}
\hline $\begin{array}{l}\text { Brceding } \\
\text { centre }\end{array}$ & Wickham clones \\
\hline \multicolumn{2}{|l|}{ Malaysia } \\
\hline PB & 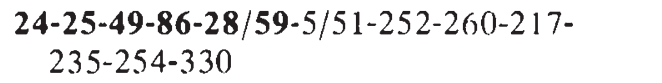 \\
\hline RRIM & $\begin{array}{l}501-511-519-600-603-605-607-612-622-623 \\
\quad 701-703-707\end{array}$ \\
\hline Pil & A44-B 16-B84 \\
\hline \multicolumn{2}{|l|}{ Java } \\
\hline GT & 1 \\
\hline PR & $\begin{array}{l}107 \\
226-228-261-255\end{array}$ \\
\hline War & 4 \\
\hline Tjir & 1 \\
\hline $\mathrm{BR}$ & 2 \\
\hline \multicolumn{2}{|l|}{ Sumatra } \\
\hline Avros & $152-163-157-427-1328-2037$ \\
\hline \multicolumn{2}{|l|}{ Victnam } \\
\hline OY & 1 \\
\hline TB & 28 \\
\hline SUZ & $14-35$ \\
\hline IR & $7-22-35$ \\
\hline \multicolumn{2}{|l|}{ Sri Lanka } \\
\hline MK & $3 / 2$ \\
\hline $\mathrm{Nab}$ & $15-17$ \\
\hline RRIC & $\begin{array}{l}2-4-29-10()-103-110-101-102-6-22-28-37- \\
121-\end{array}$ \\
\hline \multicolumn{2}{|l|}{ Africa } \\
\hline Y & $226 / 29$ \\
\hline Har & $1-2-10-29-60-61$ \\
\hline
\end{tabular}

Clones indicated in bold are primary clones.

Leaves were dricd in an oven at $42^{\circ} \mathrm{C}$ for 3-4 days and kept in sealed plastic bags at $-200^{\circ} \mathrm{C}$.

\section{Laboratory procedure}

Total DNA was extracted from dried leaves according to the protocol of Dellaporta et al. (1983), modified by Cordesse et al. (1990), except that the extraction buffer contained $150 \mathrm{~mm}$ EDTA $\mathrm{pH} 8$, and $N$-lauroylsarcosine 1 per cent; and a proteinase $\mathrm{K}$ digestion $(50 \mathrm{mg}$ $\mathrm{ml}^{-1}, 30 \mathrm{~min}, 37^{\circ} \mathrm{C}$ ) was added following the RNase step.

Ten micrograms of DNA were digested for $4 \mathrm{~h}$ with the restriction enzyme $R s a$, according to the supplier's instructions (Appligene, Illkirch, France). Migrations were performed in 0.8 per cent agarose gels, with a Tris borate EDTA buffer, for $29 \mathrm{~h}$ at $1.5 \mathrm{~V} \mathrm{~cm}^{-1}$. After depurination in $0.25 \mathrm{~N} \mathrm{HCl}$ for $10 \mathrm{~min}$, gels were
Southern blotted onto a Nylon membrane (Hybond $\left.\mathrm{N}^{+}\right)$in $0.4 \mathrm{~N} \mathrm{NaOH}$.

Jeffreys et al. (1985a) human minisatellite probes 33.6 and $33.15(300 \mathrm{ng})$ were labelled with ${ }^{32} \mathrm{P}$ by the random primer method (Feinberg \& Vogelstein, 1983) at a specific activity of $1.5 \times 10^{8} \mathrm{cpm} \mathrm{mg}^{-1}$.

Prehybridization and hybridization were performed overnight at $42^{\circ} \mathrm{C}$ in 50 per cent formamide, $6 \times$ SSPE, $5 \times$ Denhardt, 0.5 per cent SDS and 0.8 per cent dried skimmed milk.

Membranes were washed for $30 \mathrm{~min}$ in $2 \times \mathrm{SSC}, 0.1$ per cent SDS at room temperature, $30 \mathrm{~min}$ in $2 \times \mathrm{SSC}$, (). 1 per cent SDS at $600^{\circ} \mathrm{C}, 15 \mathrm{~min}$ in $1 \times \mathrm{SSC}, 0.1$ per cent SDS at $60{ }^{\circ} \mathrm{C}$, and finally $15 \mathrm{~min}$ in $0.5 \times \mathrm{SSC}, 0.1$ per cent SDS at $60^{\circ} \mathrm{C}$, and exposed to X-ray film (Fuji NIF New RX) at $-80^{\circ} \mathrm{C}$ for $1-4$ days with two intensifying screens.

\section{Statistical analysis}

DNA fingerprints were analysed both manually and using a computer-linked autoradiograph digitalizer (I). Hoisington \& D. Gonzalez-de-Leon, unpublished observations).

To evaluate fragment patterns and statistical calculations, the Czekanowsky similarity index, $d$, was calculated for all possible pairwise comparisons, using the DISLOG program of ADDAD (1983) software. This similarity index can be transformed into the $D$ index proposed by Wetton et al. (1987), using the $D=1-d$ relation. $D$, expressing the probability that a fragment in one plant is also found in another, is $D_{\mathrm{AB}}=2 \times \mathrm{no}$. shared fragments/(no. fragments ${ }_{A}+$ no. fragments $\left.{ }_{B}\right)$.

The probability, $P$, that two different genotypes exhibit identical fragment profiles is then calculated as the average $I_{\mathrm{AB}}$ raised to the power of the mean number of fragments per genotype.

\section{Results}

We detected a large number of fragments using probe 33.15 which were superimposed on a background smear (Fig. 1). Despite the use of different hybridization conditions or higher stringency washes, this high background could not be suppressed. As the patterns obtained with probe 33.15 did not allow a clear definition of the fragments revealed, they were not further characterized.

Hybridization patterns obtained with probe 33.6 showed clearly resolved fragments (Fig. 2). All the fragments revealed by probe 33.6 occurred in 33.15 hybridization patterns. This finding suggests that the common core sequence of the human minisatellite probes (Jeffreys et al., 1985a) is responsible for the 


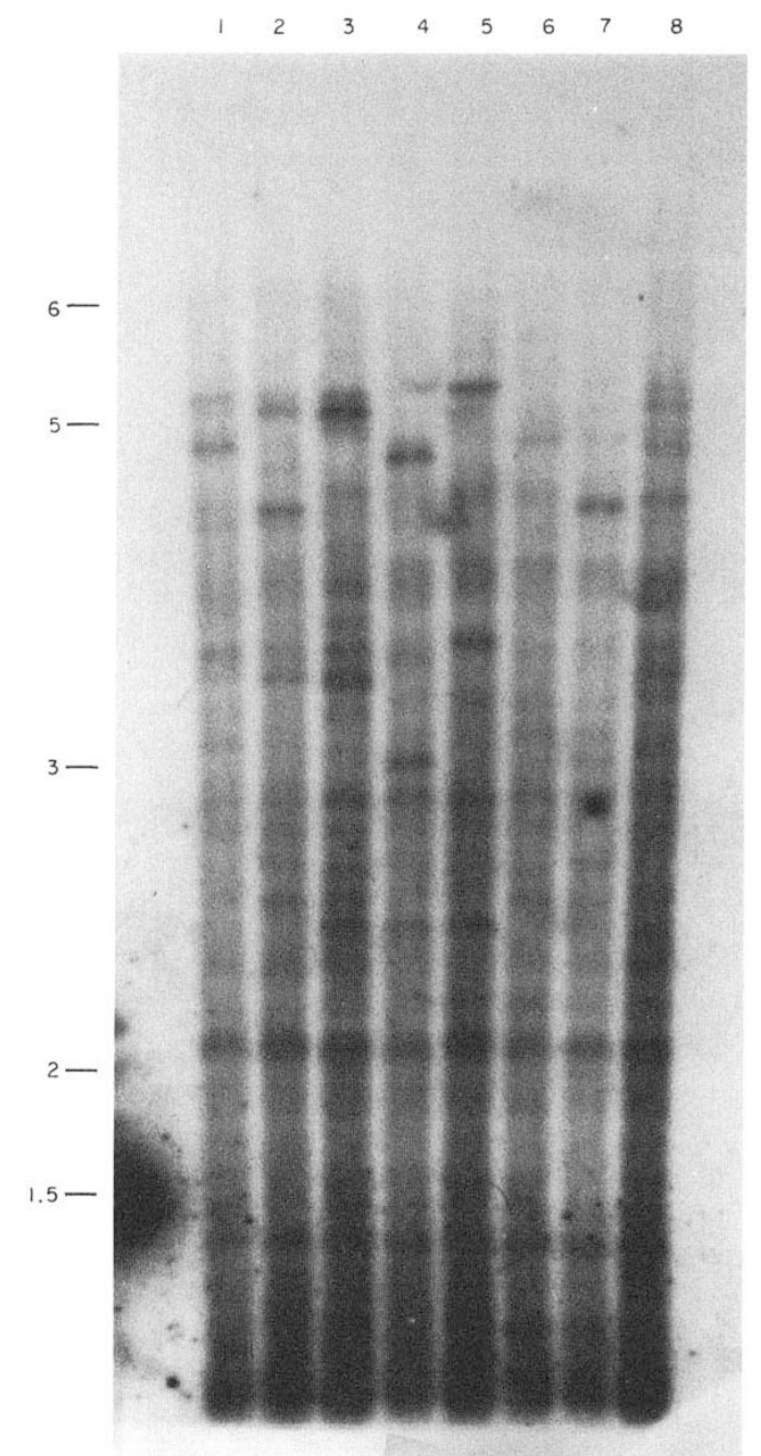

Fig. 1 RsaI digests of genomic DNA of Hevea Wickham clones, hybridized with ${ }^{32}$ P-labelled probe 33.15. Lanes 1-8: RRIM 707, RRIC 121, RRIM 703, RRIM 612, Nab 15, PB 330, Har 1, RRIC 28. Marker sizes (in kilobases) are indicated on the left.

polymorphism revealed. The more complex secondary structure of probe 33.6 could explain the absence of background smear when using this probe.

All 73 Wickham clones investigated exhibited unique DNA fragment profiles, and could be identified with this single probe associated with the restriction enzyme RsaI (Fig. 3). Hybridization patterns were reproducible and somatically stable. Indeed, different individuals of the same clone (vegetatively propagated by grafting) exhibited identical fragment profiles, showing that fragment lengths are stable through mitosis (Fig. 2). Pattern identity was not only constant in terms of the absence and presence of fragments but also in the relative intensities of fragments.

Each lane contained 4-13 discrete fragments, ranging from 1.4 to $7.4 \mathrm{~kb}$, with a mean of 5.3 polymorphic fragments per individual. A total of 17 informative fragments was resolved (plus two monomorphic low molecular weight fragments). The autoradiographic intensity differed among fragments within lanes and bore no linear relationship to fragment length. These differences could be caused by differences in sequences similarities to the probe, homozygosity, or differences in copy number in the genome. Nevertheless, intensity variations were not taken into account in statistical analysis of similarity.

The use of a computer-linked autoradiograph digitalizer for pattern analysis leads to a grouping together of some bands in the same fragment classes (Fig. 3). Indeed, due to the large number of individuals analysed, we had to choose a medium threshold for determination of cluster distances in order to avoid any improper reading of blots. Therefore, for statistical calculations, those multiple bands phenotypes were considered as a single fragment, leading to an overestimation of the $X_{D}$ value.

$D$-values were calculated for all possible comparisons (2628), and gave an average $X_{D}=0.414$. ( $D$ values for primary clones are shown in Table 2.) Thus, the probability of fragment profiles being identical by chance could be calculated to give $P=9.3 \times 10^{-3}$.

Except for primary clones, pedigrees of Wickham clones are generally well known. Thus, fragment inheritance could be assessed by examining some genealogies (Fig. 4). As each fragment in the offspring could be traced back to one or other parent, we could assume that minisatellite fragments are stably inherited.

\section{Discussion and conclusion}

Sequences homologous to 33.15 appear to be highly abundant and widespread throughout the Hevea genome, leading to a high background smear, making this probe unsuitable for fingerprinting Hevea clones. Therefore, optimal probe/species combinations that give convenient banding patterns have to be determined empirically, as already demonstrated by hybridizations of human minisatellite probes (Dallas, 1988; Braithwaite \& Manners, 1989), M13-derived probes (Ryskov et al., 1988; Zimmerman et al., 1989; Rogstad et al., 1988b), and simple repetitive sequences (Walmsley et al., 1989; Weising et al., 1991) to plant and fungal genomes.

On the other hand, probe 33.6 is a valuable tool for clonal identification of cultivated Hevea brasiliensis clones. Indeed, despite their narrow genetic base, all 


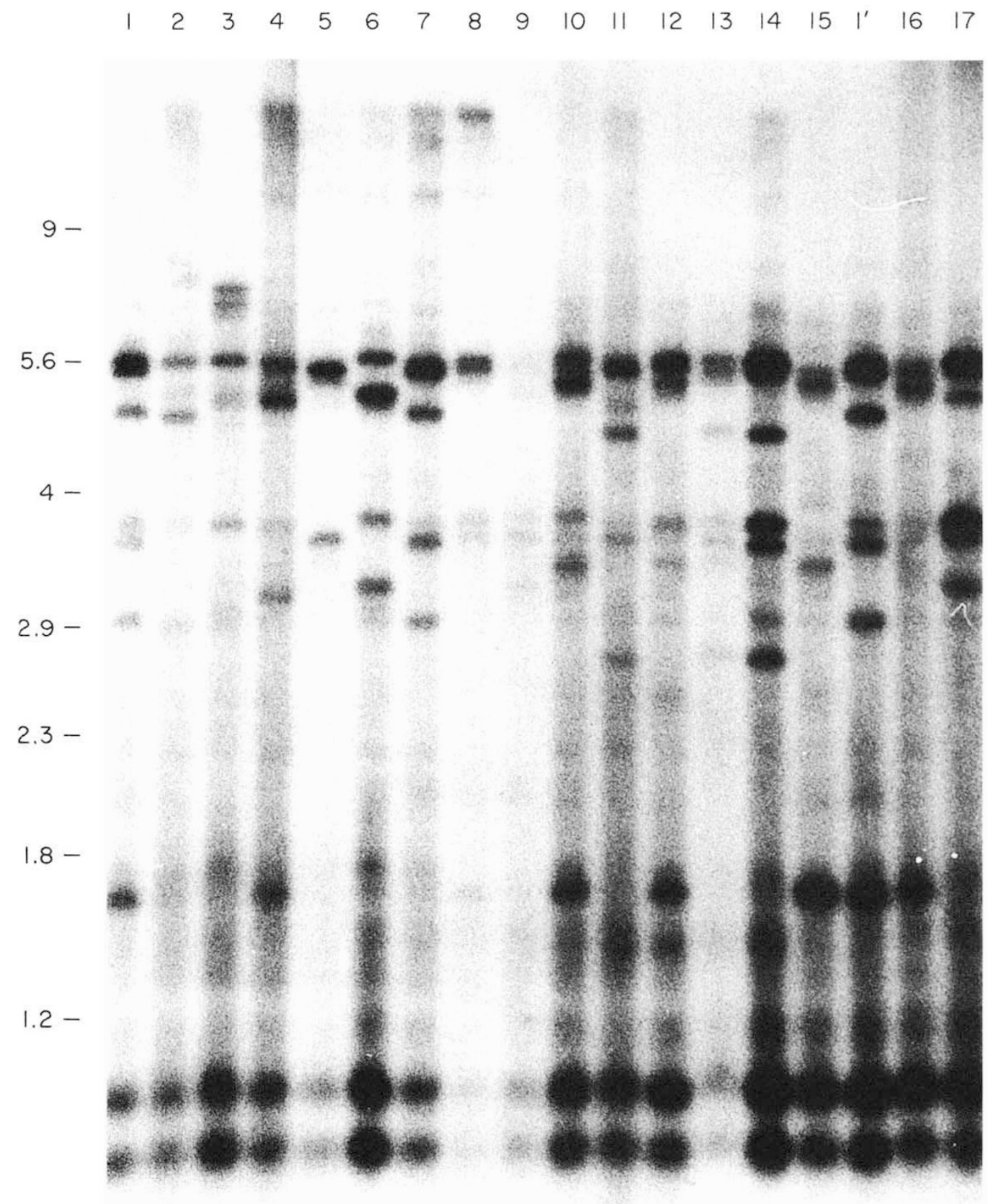

Fig. 2 Rsa 1 digests of genomic DNA of Hevea Wickham clones, hybridized with ${ }^{32} \mathrm{P}-$ labelled probe 33.6. Lanes 2-17: PB 24, PB 25, PB 49, PB 86, PB 254, PB 28/59, RRIC 2, RRIC 28, RRIC 29, RRIC 103, OY 1, IR 22, IR 35, SUZ 14, PR 255, PR 228. Lanes 1 and $1^{\prime}$ are two different individual trees of the GT1 clone. Marker sizes (in kilobases) are indicated on the left.

the Wickham clones studied can be identified with this single probe. The $X_{D}$ value $(0.414)$ shows that a relatively high level of polymorphism (in terms of fingerprint identity) has been maintained in this population. Indeed, cultivated clones have on average less than half of their fragments in common. It was not possible to study Hevea variability accurately at the place of origin of Wickham clones. However, the effects of selection and domestication can be evaluated by examining $D$ values in primary clones (Table 2 ). The wide range of 

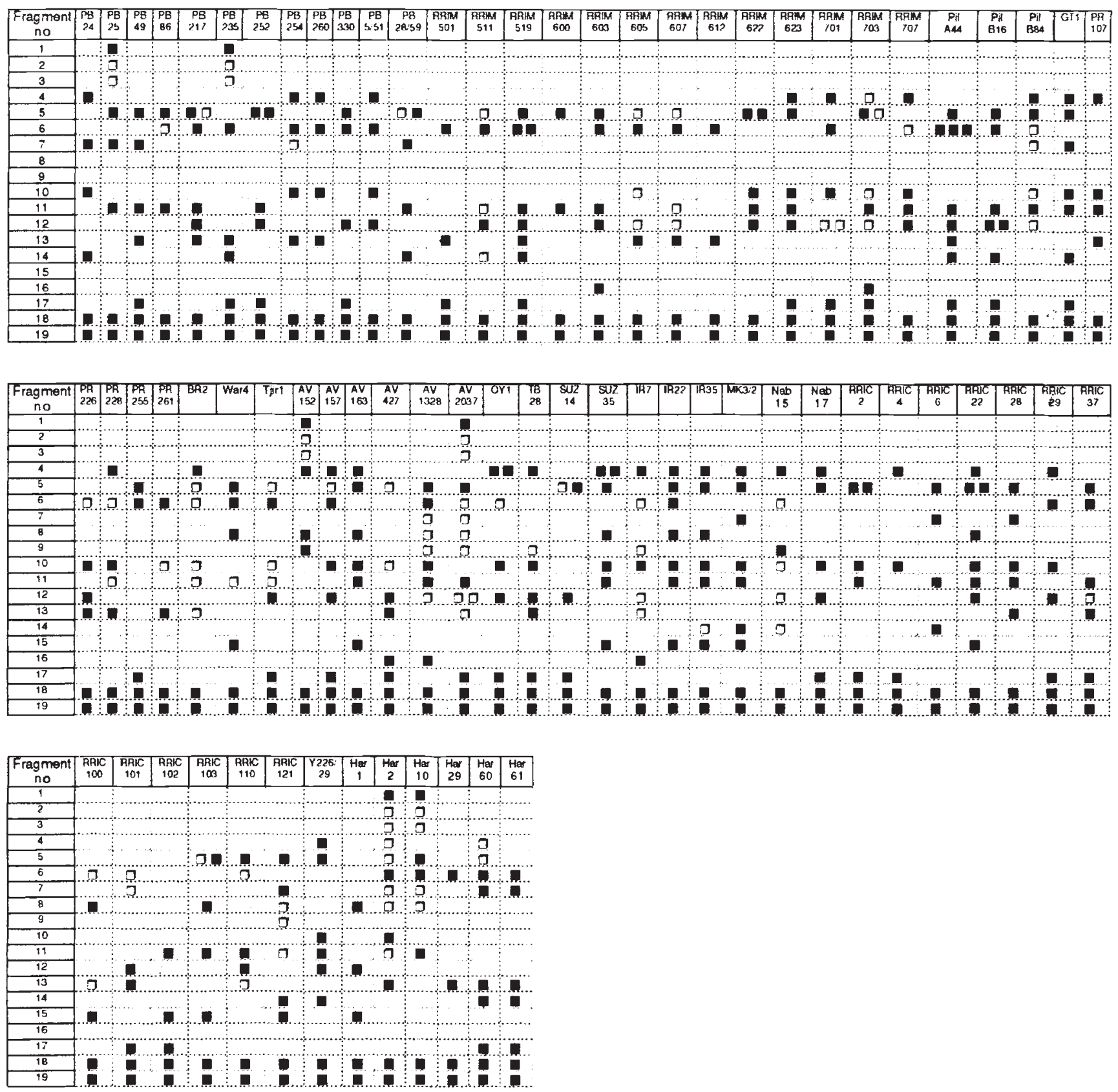

Fig. 3 Fingerprint patterns of the 73 Wickham clones, obtained with the probe enzyme combination 33.6/RsaI. Differences in band intensities are represented ( $\square)$ for high intensity and ( $\square$ ) for faint bands.

similarity values (from 0 to 0.92 ) found in this primary population confirms isozyme data (Soleille, 1984; Chevallier, 1988) because all these results suggest that the genetic basis of Wickham seeds was sufficient to be maintained by an effective mass selection and then fixed by asexual propagation of clones to give a relatively polymorphic primary population.

Minisatellite investigations conducted to date in plants have estimated chance occurrences of identical fragment patterns to be generally higher than those found in humans (Jeffreys et al., 1985b) and birds (Wetton et al., 1987), which are about $10^{-11}$ and $10^{-14}$ for unrelated individuals, respectively. Nevertheless, in some plant species, the chance of fingerprint identity can be relatively low. Indeed, distant rice cultivars give an identity probability of $10^{-11}$ (Dallas, 1988), and a study of several species of Rubus reveals probabilities ranging from $10^{-8}$ to $10^{-6}$ (Nybom et al., 1990a). 
索

華

莡

$\frac{\sqrt[3]{2}}{0}$



ถี

そึก

กิ

in

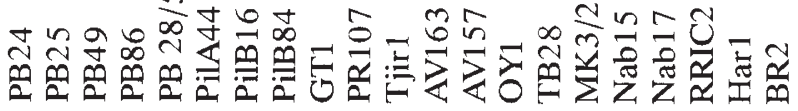

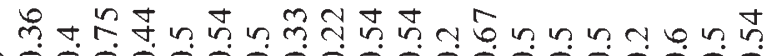
000000000000000000000

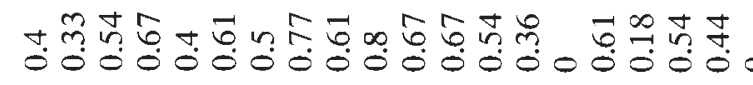

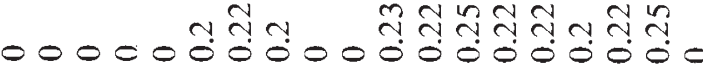

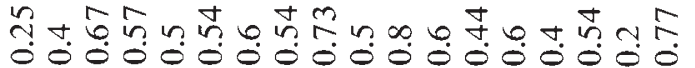

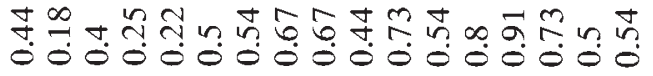

虽

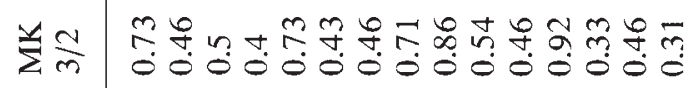

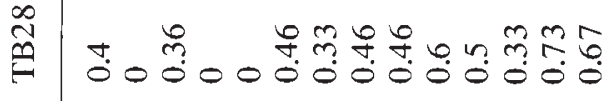

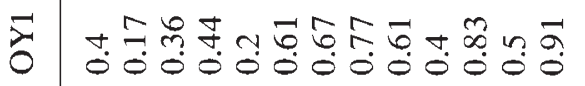

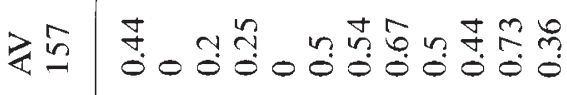

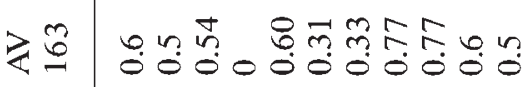

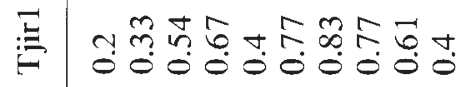

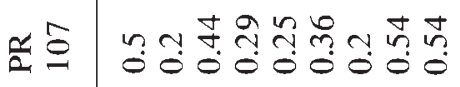

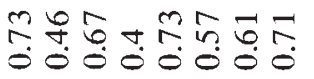

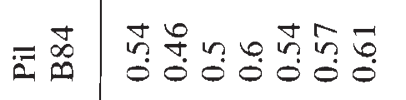

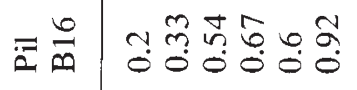

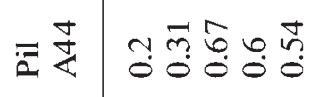

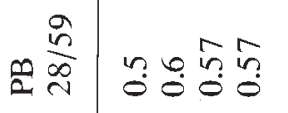

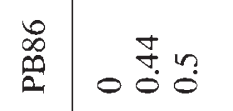

จิ สี่

खิ तิ

$\cong$ กี่ 
However, larger values have been reported, mainly when the plants involved were closely related. $P$ is about $10^{-3}$ among closely related blackberry cultivars (Nybom et al., 1989), $10^{-2}$ for box elder (Nybom \& Rogstad, 1990), about $10^{-2} / 10^{-3}$ within species of Rubus (Nybom \& Schaal, 1990a), and $10^{-5}$ and $10^{-4}$ (respectively) for Malus and Prunus cultivars (Nybom et al., 1990). The chance identity probability of $9.3 \times 10^{-3}$ found in the present study is consistent with these data because the Hevea brasiliensis population studied consists of closely related individuals.

As patterns are reproducible, somatically stable, and fragments stably inherited, probe 33.6 provides a powerful new tool for the identification of cultivated Hevea clones as an alternative to isozymatic markers. Indeed because DNA fingerprinting can be performed on simply dried leaves, the supply of plant material from foreign countries for identification purposes will be considerably simplified. Furthermore, DNA fingerprinting allows identification of some clones that could not be differentiated by isozyme study (M. Segvin and M. H. Chevallier, unpublished data). PB 24 and PB 5/51 (parent/offspring), and RRIM 701 and RRIM 707 (half sibs) are identified by DNA fingerprint while they exhibited the same isoenzyme patterns despite the study of 12 enzymatic system (representing 35 alleles). Thus, fingerprinting, despite the quite low number of fragments revealed compared with other species, appears to be a powerful technique for clonal identification in cultivated clones of Hevea brasiliensis.

Identification studies have already been performed using DNA fingerprints simply as 'phenotypic' tools (searching for the presence or absence of fragments), but we are now attempting to evaluate the genetic significance of the fragments discovered. Hybridization with common minisatellite probes usually results in only one fragment per locus. Most bands represent independent loci in humans (Jeffreys et al., 1985a, 1986), birds (Burke \& Brudford, 1987), or rice (Dallas, 1988), but higher levels of linkage have been demonstrated in mice (Jeffreys et al., 1987), dogs, cats (Jeffreys \& Morton, 1987), and apples (Nybom \& Schaal, 1990b). Preliminary results on Hevea using clone genealogies, according to pedigree analysis, as performed by Jeffreys et al. (1985a), indicate that most Wickham clones appear to be heterozygous for many minisatellite fragments, as found also in minisatellite analysis of other cross-fertilizing species (Jeffreys et al., 1985b; Jeffreys \& Morton, 1987; Burke \& Brudford, 1987; Wetton et al., 1987; Nybom \& Schaal, 1990b), and that at least six different loci should be revealed in our fingerprints, four being not tightly linked. These first results bode well for further detailed investigations on the genetics of Hevea fingerprints, allowing them to

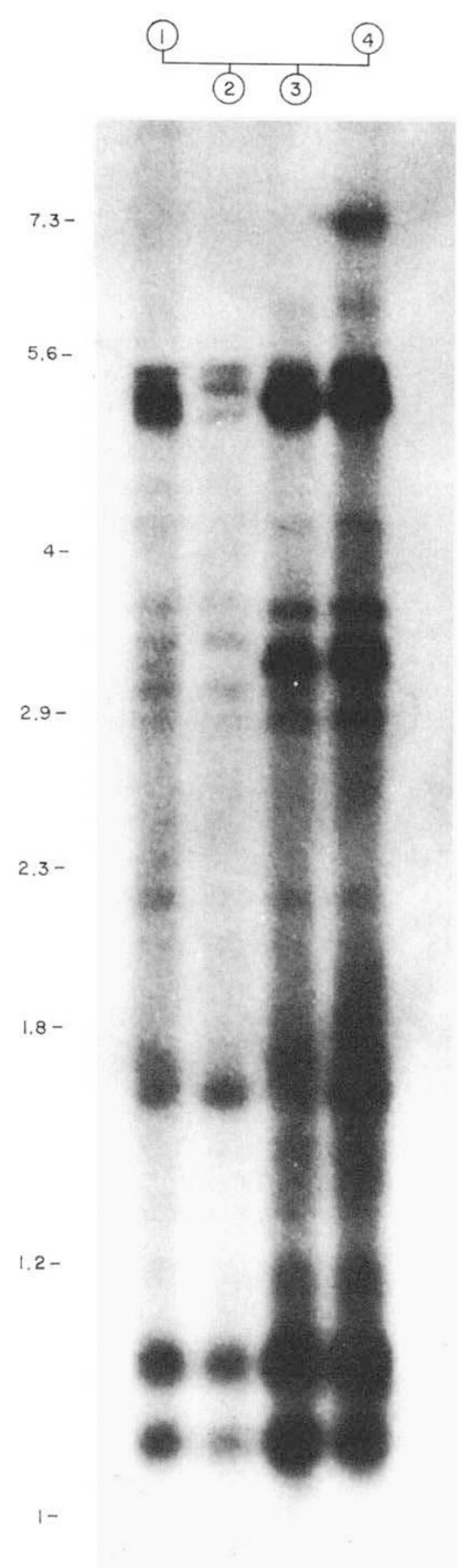

Fig. 4 Example of a pedigree involving four of the Wickham clones. (RsaI digests of genomic DNA hybridized with ${ }^{32} \mathrm{P}-$ labelled probe 33.6.) Lanes 1-4: Pil A44, RRIM 519, RRIM 511, Pil B16. Marker sizes (in kilobases) are indicated on the left.

be used as real genetic markers. Special crosses must be performed in Hevea in order to specify levels of allelism and genetic linkage in our fingerprints. 
Therefore, minisatellite probe 33.6 can be used as powerful new tool for clonal identification, and it will be useful for paternity testings in seed gardens (Simmonds, 1986), as for apple trees (Nybom \& Schaal, 1990b). This probe can also be used for legitimacy controls of crosses in breeding programmes.

\section{Acknowledgements}

We would like to thank A. Clément-Demange (IDEFOR-dpl, Côte d'Ivoire), who provided us with plant material; D. Nicolas (IRCA-CIRAD) for his interest in this work; D. Gonzalez-de-Leon (IRFACIRAD) for advice in pattern analyses and Professor F. Quétier (Paris Sud-Orsay University) for helpful comments and suggestions.

\section{References}

ADDAD, 1983. Manuel de reference. Association pour le developpement et la diffusion de l'analyse des données, Paris.

BRAITHWAITE, K. S. AND MANNERS, J. M. 1989. Human hypervariable minisatellite probes detect DNA polymorphisms in the fungus Colletotrichum gloeosporioides. Curr. Genet., 16, 473-475.

BURKE, T. AND BRUDFORD, M. w. 1987. DNA fingerprinting in birds. Nature, 327, 149-152.

CHEVALLIER, M. H. 1988. Genetic variability of Hevea brasiliensis germplasm using isozyme markers. J. Nat. Rubb. Res., 3, 42-53.

CORDESSE, F., SECOND, G. AND DELSENY, M. 1990. Ribosomal gene spacer length variability in cultivated and wild rice species. Theor. Appl. Genet., 79, 81-88.

DALLAS, J. F. 1988. Detection of DNA 'fingerprints' of cultivated rice by hybridization with a human minisatellite DNA probe. Proc. Natl. Acad. Sci., U.S.A., 85, 6831-6835.

DELLAPORTA, S. L., WOOD, J. AND HICKS. J. B. 1983. A plant DNA preparation. Version II. Plant. Mol. Biol. Rep., 4, 19-21.

FEINBERG, A. P. AND VOGELSTEIN, B. 1983. A technique for radiolabelling DNA restriction endonuclease fragments to high specific activity. Anal. Biochem., 132, 6-13.

JEFFREYS, A. J. AND MORTON, D. B. 1987. DNA fingerprints of dogs and cats. Anim. Genet., 8, 1-15.

JEFFREYS, A. J., WILSON, V., KELLY, R., TAYLOR, B. A. AND BULFIELD, G. 1987. Mouse DNA 'fingerprints': analysis of chromosome localization and germ-line stability of hypervariable loci in recombinant inbred strains. Nucl. Acids Res., 15, 2832-2836.

JEFFREYS, A. J., WILSON, V. AND THEIN, S. L. 1985a. Hypervariable 'minisatellite' regions in human DNA. Nature, 314, $67-73$

JEFFREYS, A. J., WILSON, v. AND THEIN, S. L. 1985b. Individualspecific 'fingerprints' of human DNA. Nature, 316, 76-79.

JEFFREYS, A. J., WILSON, V., THEIN, S. L., WEATHERALL, D. J. AND PONDER, B. A. J. 1986. DNA 'fingerprints' and segregation analysis of multiple markers in human pedigrees. Am. $J$. Hum. Genet., 39, 11-24.
Lebrun, P. AND Chevallier, M. H. 1990. Starch and Polyacrylamide Gel Electrophoresis of Hevea brasiliensis: a Laboratory Manual. IRCA/CIRAD, Montpellier, France.

NYBOM, H. AND RoGSTAD, S. H. 1990. DNA 'fingerprints' detect genetic variation in Acer negundo (Aceraceae). Pl. Syst. Evol., 173, 49-56.

NYBOM, M., ROGSTAD, S. H. AND SCHAAL, B. A. 1990. Genetic variation detected by use of the M13 'DNA fingerprint' probe in Malus, Prunus, and Rubus (Rosaceae). Theor. Appl. Genet., 79, 153-156.

NYBOM, H. AND SCHAAL, B. A. 1990a. DNA 'fingerprints' reveal genotypic distributions in natural populations of blackberries and raspberries (Rubus, Rosaceae). Am. J. Bot., 77, 883-888.

NYBOM, H. AND SCHAAL, B. A. 1990b. DNA 'fingerprints' applied to paternity analysis in apples (Malus $\times$ domestica). Theor. Appl. Genet., 79, 763-768.

NYBOM, H., SCHAAL, B. A. AND ROGSTAD, S. H. 1989. DNA 'fingerprints' can distinguish cultivars of blackberries and raspberries. Acta Hortic., 262, 310-315.

ROGSTAD, S. H., PATTON, J. C. AND SCHAAL, B. A. 1988a. Human minisatellite probe reveals RFLPs among individuals of two angiosperms. Nucl. Acids Res., 16, 11378.

Rogstad, S. H., PATTON II, J. C. AND SChAAL, B. A. 1988b. M13 repeat probe detects DNA minisatellite-like sequences in gymnosperms and angiosperms. Proc. Natl. Acad. Sci., U.S.A., 85, 9176-9178.

RYSKOV, A. P., JINCHARADZE, A. G., PROSNYAC, M. I., IVANOV, P. L. AND LIMBORSKA, S. A. 1988. M13 phage as a universal marker for DNA fingerprinting of animals, plants and microorganisms. FEBS Lett., 233, 388-392.

SIMMONDS, N. W. 1986. Theoretical aspects of synthetic/ polycross populations of rubber seedlings. J. Nat. Rubb. Res., 1, 1-15.

SOLEILlE, B. 1984. Etude de la variabilité enzymatique chez Hevea brasiliensis: recherche du déterminisme génétique et analyse des premières introductions en sélection. Thèse de Doctorat. Université de Paris Sud-Orsay.

VASSART, G., GEORGES, M., MONSIEUR, R., BROCAS, H., LEQUARRE, A. S. AND CHRISTOPHE, D. 1987. A sequence in M13 phage detects hypervariable minisatellites in human and animal DNA. Science, 235, 683-684.

WALMSLEY, R. M., WILKINSON, B. M. AND KONG, T. H. 1989. Genetic fingerprinting for yeasts. Biotechnology, 7, 1168-1170.

WEISING, K., BEYERMANN, B., RAMSER, J. AND KAHL, G. 1991. Plant DNA fingerprinting with radioactive and deoxygenated oligonucleotide probes complementary to simple repetitive DNA sequences. Electrophoresis, 12, 159-169.

WEISING, K., FREIGAND, F., DRIESEL, A. J., KAHL, G., ZISCHLER, H. AND EPPLEN, J. T. 1989. Polymorphic simple GATA/GACA repeats in plant genomes. Nucl. Acids Res., 17, 10128.

WEISING, K. AND KAHL, G. 1990. DNA fingerprinting in plants: the potential of a new method. Biotech-Forum Europe, 7, 230-235.

WETTON, J. H., CARTER, R. E., PARKIN, D. T. AND WALTERS, D. 1987. Demographic study of a wild house sparrow population by DNA fingerprinting. Nature, 327, 147-149.

ZIMMERMAN, P. A., LANG-UNNASCH, N. AND CULLIS, C. A. 1989. Polymorphic regions in plant genomes detected by an M13 probe. Genome, 32, 824-828. 